\title{
Serum cholesterol and cholesterol and lipoprotein metabolism in hypercholesterolaemic NIDDM patients before and during sitostanol ester-margarine treatment
}

\author{
H. Gylling, T. A. Miettinen \\ Second Department of Medicine, University of Helsinki, Helsinki, Finland
}

\begin{abstract}
Summary Cholesterol absorption and metabolism and LDL and HDL kinetics were investigated in 11 hypercholesterolaemic non-insulin-dependent diabetic men off and on a hypolipidaemic treatment with sitostanol ester, ( $3 \mathrm{~g}$ sitostanol daily) dissolved in rapeseed oil margarine, by a double-blind crossover study design. Serum total, VLDL and LDL cholesterol and apoprotein B fell significantly by $6 \pm 2,12 \pm 6,9 \pm 3$ and $6 \pm 2 \%$, mean \pm SEM, and HDL cholesterol was increased by $11 \pm 4 \%(p<0.05)$ by sitostanol ester. LDL cholesterol and apoprotein B were significantly decreased in the dense $(1.037-1.055 \mathrm{~g} / \mathrm{ml})$, but not light, LDL subfraction due to a significantly diminished transport rate for LDL apoprotein $\mathrm{B}$, while the fractional catabolic rate was unchanged. HDL kinetics, measured with autologous apoprotein A I, was unaffected by sitostanol ester. Cholesterol absorption efficiency was markedly reduced from $25 \pm 2$ to $9 \pm 2 \%(p<0.001)$ during sitostanol ester followed by proportionately decreased serum plant sterol proportions. Cholesterol precursor sterol
\end{abstract}

proportions in serum, fecal neutral sterol excretion, and cholesterol synthesis, cholesterol transport, and biliary secretion were all significantly increased by sitostanol ester. We conclude that the sitostanol ester-induced decrease in cholesterol absorption compensatorily stimulated cholesterol synthesis, had no effect on fractional catabolic rate, but decreased transport rate for LDL apoprotein B so that serum total, VLDL and LDL cholesterol levels were decreased. Dietary rapeseed oil margarine rich in sitostanol ester was well tolerated, appears to be safe from the nutritional point of view and effective for lowering VLDL and LDL cholesterol and increasing HDL cholesterol in hypercholesterolaemic non-insulin-dependent diabetic subjects. [Diabetologia (1994) 37:773-780]

Key words Cholesterol, cholesterol absorption, cholesterol synthesis, lipoprotein kinetics, sitostanol, plant sterols, precursor sterols, non-insulin-dependent diabetes.
Received: 13 December 1993

and in revised form: 10 March 1994

Corresponding author: Dr. T. A. Miettinen, Second Department of Medicine, University of Helsinki, Haartmaninkatu 4, FIN00290 Helsinki, Finland

Abbreviations: Apo, apoprotein; NIDDM, non-insulin-dependent diabetes mellitus; VLDL, very low density lipoprotein; IDL, intermediate density lipoprotein; LDL, low density lipoprotein; HDL, high density lipoprotein; FCR, fractional catabolic rate; $\mathrm{TR}$, transport rate.

Presented in part at the 65 th Scientific Sessions of the American Heart Association, New Orleans, November 1992 (Circulation 1992; 86[Supp1 I]: I-404)
NIDDM is associated with accelerated atherosclerosis, and the risk of coronary artery disease is three- to fourfold increased compared with the non-diabetic population [1-3]. Atherogenic risk factors are the same in NIDDM as in the general population [4], although the occurrence of hypercholesterolaemia is less consistent, and hypertriglyceridaemia and low HDL cholesterol levels are the frequently observed lipid abnormalities.

Plant sterols, particularly sitosterol, have been known since the 1950 s to reduce serum cholesterol by inhibiting cholesterol absorption [5-13], but the large doses needed and the crystalline form has limited its wider use. Sitostanol is a $5 \alpha$-saturated derivative of sitosterol. It lowers the serum cholesterol level more effectively than sitosterol [14], and is completely unab- 
sorbable in humans [15-17]. In addition, sitostanol ester is fat soluble which facilitates its consumption e.g. when dissolved in rapeseed oil mayonnaise [16-17]. In normal subjects cholesterol absorption efficiency and cholesterol synthesis are inversely interrelated and regulate serum total and LDL cholesterol levels [18, 19]. In a recent study, small amounts of sitostanol ester reduced cholesterol absorption efficiency by $5 \%$ and LDL cholesterol level by $7 \%$, and with larger doses of sitostanol the reduction of LDL cholesterol was more marked [17]. The question now arises whether serum total and LDL cholesterol could be diminished by sitostanol ester in hypercholesterolaemic patients with NIDDM and with similar mechanisms as in normal subjects. Very little is known about cholesterol absorption in NIDDM, and interrelations between cholesterol absorption and synthesis, LDL receptor activity and LDL cholesterol levels have not been studied in these patients either. Accordingly, the aim of the present study was to investigate the suitability and the mode of action of a margarine with a high sitostanol ester content for the hypolipidaemic treatment of hypercholesterolaemic NIDDM men by studying changes in serum lipids, cholesterol absorption, and cholesterol, LDL and HDL metabolism.

\section{Subjects and methods}

Subjects. The study group consisted of 11 NIDDM men with a mean age of $57.8 \pm 1.9$ (SEM) years. None of the patients were undergoing insulin or hypolipidaemic therapy. Three patients were on diet only, five were treated orally with glibenclamide and two with biguanides, and two were on a combination therapy of these two regimens. The glycaemic control was good to moderate during the metabolic studies with a mean blood glucose value of $8.9 \pm 0.5 \mathrm{mmol} / \mathrm{l}$ and glycated haemoglobin of $7.6 \pm 0.5 \%$. None of the patients had microalbuminuria, retinoor neuropathia or hepatic or gastrointestinal diseases. One patient had been treated with thyroxin for several years. His serum thyroid stimulating hormone (TSH) level was normal, $5.0 \mathrm{mU} / \mathrm{l}$. Four patients used calcium channel blockers, three were treated with beta blocking agents, two with angiotensin converting enzyme inhibitors and two with isosorbide mononitrates. Two subjects were only being treated with glibenclamide. Neither their weight nor serum lipids, dietary nor metabolic parameters differed from those subjects taking other medications. In addition, serum cholesterol and the metabolic parameters did not differ between patients with or without beta blocking therapy. All the subjects volunteered for the study, which had been approved by the Ethical Committee of the University Hospital.

Study design. After a run-in period of 4 weeks with the subjects eating their normal diet, a control period of 6 weeks was started, during which five of the subjects consumed $30 \mathrm{~g}$ of rapeseed oil margarine daily followed by a 6-week treatment period, during which $30 \mathrm{~g}$ of margarine was dissolved with sitostanol ester $(3 \mathrm{~g}$ sitostanol/day) into three $10 \mathrm{-g}$ buttons. One of the buttons was spread on a sandwich during each of the three daily meals. Six of the patients started first with the sitostanol ester margarine followed by the pure margarine period. The subjects continued unchanged with their regular diets except for a reduction in fat in- take respective to the $30 \mathrm{~g}$ of daily rapeseed oil margarine, according to detailed instructions of our dietician. The study was completed as an outpatient study on a cross-over, double-blind basis. This was possible because the two types of margarines had similar taste and appearance, and the subjects could not distinguish between the different periods.

The rapeseed oil margarine contained plant sterols campesterol, sitosterol and avenasterol 209, 288 and $19 \mathrm{mg} / 100 \mathrm{~g}$ of margarine, respectively. Sitosterol was hydrated to sitostanol (Kaukas Inc., Lappeenranta, Finland) and transesterified with rapeseed oil fatty acids and dissolved in the margarine as $1 \mathrm{~g} / 10 \mathrm{~g}$ buttons (Raisio Inc., Raisio, Finland).

At the end of the control and sitostanol ester treatment periods, metabolic and kinetic studies were performed. The subjects kept a food record for 7 days, from which the dietary constituents were calculated [20]. Also, they were given a capsule containing $4-{ }^{14} \mathrm{C}$-cholesterol, $22,23^{3} \mathrm{H}$-beta-sitosterol, and $200 \mathrm{mg}$ $\mathrm{Cr}_{2} \mathrm{O}_{3}$ three times a day with their regular meals during the 7-day period. Cholesterol absorption and fecal steroids were analysed from a 3-day stool collection. During the LDL and HDL turnover studies serum lipids, lipoproteins and apoproteins and serum non-cholesterol sterols were analysed four times from serum samples after a 12 -h fast. The glycaemic control was monitored during each 6-week period by analysing fasting blood glucose and urine sediment four times and glycated haemoglobin and the presence of microalbuminuria twice.

Methods. Serum total and free cholesterol, triglycerides, phospholipids and apo A I, A II and B were analysed with commercial kits (Boehringer Diagnostica, Mannheim Germany; Wako Chemicals, Germany, and Orion Diagnostica, Espoo Finland). Serum lipoproteins were separated by ultracentrifugation into density classes as described previously [21]. $\mathrm{HDL}_{2}$ and $\mathrm{HDL}_{3}$ were separated by ultracentrifugation. In addition, LDL was fractionated into subfractions by density gradient ultracentrifugation [22]. The LDL subfractions of hydrated densities from 1.019 to $1.036 \mathrm{~g} / \mathrm{ml}$ (light LDL) and from 1.037 to $1.055 \mathrm{~g} / \mathrm{ml}$ (dense LDL) were pooled separately.

Serum cholesterol precursors squalene, $\Delta 8$-cholestenol, desmosterol and lathosterol, and serum plant sterols campesterol and sitosterol, and cholestanol, were quantitated by gas-liquid chromatography on a 35-m long SE-30 capillary column [22,23]. The serum values are expressed in terms of $10^{2} \mathrm{mmol} / \mathrm{mol}$ of cholesterol.

Cholesterol ester transfer protein activity was measured according to a method described by Groener et al. [24]. Vitamin E concentration was measured with HPLC [25], and sialic acids by a calorimetric reaction $[26,27]$. Cholesterol absorption was measured by the peroral double-isotope continuous feeding method [28] and by analysing serum plant sterol levels. Chromic oxide was analysed from the 3-day fecal specimen [29] and fecal sterols with gas-liquid chromatography using the 50-m long SE30 capillary column $[23,30,31]$. Cholesterol synthesis and its changes were measured by the sterol balance technique and the cholesterol precursor sterol proportions in serum.

For the kinetic studies, after the subjects had fasted $50 \mathrm{ml}$ of EDTA plasma was drawn, and autologous HDL and autologous total and dense LDL were separated by serial preparative ultracentrifugations. Apo A I was isolated from HDL as described previously [32]. Dense LDL and HDL were iodinated with ${ }^{125} \mathrm{I}$ and total LDL with ${ }^{131} \mathrm{I}$ by a modification of the iodinemonochloride method $[33,34]$. Three days before injection the subjects started to take peroral potassium iodide. Approximately $1 \mathrm{mg}$ of the labelled total LDL and apo A I and $0.5-1 \mathrm{mg}$ of dense LDL were mixed with $5 \%$ human serum albumin, filtered, and injected simultaneously. The total amount of radioactivity varied from 40 to $50 \mu \mathrm{Ci}$. 
Table 1. Weight, body mass index and dietary parameters before and during sitostanol ester treatment in eleven NIDDM men

\begin{tabular}{|c|c|c|}
\hline Parameters & Control & Sitostanol ester \\
\hline Weight (kg) & $81.2 \pm 3.1$ & $80.8 \pm 3.0$ \\
\hline Body mass index $\left(\mathrm{kg} / \mathrm{m}^{2}\right)$ & $26.5 \pm 0.7$ & $26.4 \pm 0.7$ \\
\hline Dietary cholesterol (mg/day) & $324.4 \pm 39.5$ & $356.8 \pm 43.2$ \\
\hline Dietary fat (g/day) & $92.1 \pm 7.3$ & $98.6 \pm 7.7$ \\
\hline $\begin{array}{l}\text { Calorie intake } \\
\left(\mathrm{kcal} \cdot \mathrm{kg}^{-1} \cdot \text { day }^{-1}\right)\end{array}$ & $26.8 \pm 1.3$ & $28.8 \pm 2.1$ \\
\hline Dietary campesterol $^{\mathrm{b}}$ (mg/day) & $114 \pm 8$ & $129 \pm 8$ \\
\hline Dietary sitostanol ${ }^{\mathrm{b}}$ (mg/day) & $29 \pm 4$ & $3091 \pm 172^{\mathrm{a}}$ \\
\hline Blood glucose $(\mathrm{mmol} / \mathrm{l})$ & $8.8 \pm 1.3$ & $9.0 \pm 1.1$ \\
\hline Glycated haemoglobin (\%) & $7.5 \pm 0.7$ & $7.6 \pm 0.7$ \\
\hline Serum vitamin $E(\mu \mathrm{mol} / 1)$ & $50.9 \pm 4.3$ & $45.9 \pm 4.1$ \\
\hline
\end{tabular}

Data given as mean \pm SEM.

${ }^{\mathrm{a}} p<0.001$; $^{\mathrm{b}}$ Measured from fecal sterols

After the injection, blood samples of $10 \mathrm{ml}$ were collected and the radioactivity counted for 14 days. The die-away curves were constructed in whole plasma for ${ }^{131} \mathrm{I}$ total LDL and after ultracentrifugation for ${ }^{125} \mathrm{I}$ dense LDL and ${ }^{125} \mathrm{I}$ HDL. FCR for total and dense LDL and apo A I HDL were determined using a two-pool model [35]. TR was calculated by multiplying FCR by the pool size, which was calculated to be $4.5 \%$ of body weight. LDL density gradient spin was performed four times from the post-injection samples. Cholesterol, apo B and sialic acid contents were measured from the fractions, and TR for dense LDL was calculated similarly to total LDL. The FCR and TR for light LDL were calculated from the total and dense kinetic data.

Calculations. Cholesterol synthesis was calculated as the difference between the fecal steroids (neutral and acidic) of cholesterol origin and dietary cholesterol. Total intestinal cholesterol flux was calculated by dividing fecal neutral sterols by (1-fractional cholesterol absorption). Cholesterol transport or turnover was the sum of cholesterol synthesis and absorbed dietary cholesterol (cholesterol absorption efficiency multiplied by dietary cholesterol). Biliary cholesterol secretion was calculated as total intestinal flux minus dietary cholesterol.

\section{Statistical analysis}

Statistical significances were tested with two-tailed Student's $t$-test, paired $t$-test and analysis of variance with repeated measurements. Correlations were calculated as Pearson's productmoment correlation coefficients. A $p$-value of less than 0.05 was considered statistically significant.

\section{Results}

All subjects completed the studies, and the sitostanol ester dissolved in rapeseed oil margarine was well tolerated. Weight, body mass index, glycaemic control and serum vitamin $\mathrm{E}$ levels (even without correction for changes in lipoprotein levels) and daily cholesterol, fat and calorie intakes were similar during the control and sitostanol ester treatment periods (Table 1). The compliance was good as indicated by the increase of fecal sitostanol output from $29 \mathrm{mg} /$ day to $3091 \mathrm{mg} /$ day.

Lipoprotein concentrations. Serum total, VLDL and LDL cholesterol were significantly lowered by $6 \pm 2$, $12 \pm 6$ and $9 \pm 3 \%$, respectively, and HDL cholesterol was $11 \pm 4 \%$ higher during sitostanol ester treatment (Tables 2 and 3). Serum triglyceride and phospholipid levels were unchanged. In serum and VLDL and IDL the amount of esterified cholesterol was reduced while free cholesterol, triglycerides and phospholipids did not show a constant change. However, in the LDL particle both esterified and free cholesterol as well as phospholipids and apo B were significantly lowered. The cholesterol/apo B ratio was significantly reduced in LDL, but LDL size was practically unchanged. Subfractionation of LDL showed that no significant changes were occurring in the light fraction, while cholesterol and apo B were significantly reduced in the dense fraction, and a significant elevation of apo $B$ and a reduction in the cholesterol/apo B ratio was found in the very dense $(1.056-1.063 \mathrm{~g} / \mathrm{ml})$ fraction.

The sialic acid content in LDL was significantly reduced $(28 \pm 6 \%)$ by sitostanol ester, but the respective sialic acid/apo B ratio only tended to decrease from $63.6 \pm 6.3$ to $48.0 \pm 4.7 \mu \mathrm{g} / \mathrm{mg}(p=0.06)$. The decrease was exclusively found in the dense LDL subfraction.

In HDL, free, and to a lesser extent esterified cholesterol, and apo A I were significantly elevated by $15 \pm 5$ and $4 \pm 2 \%$, respectively (Table 2 ), while the increment of phospholipids and apo A II were less consistent. Cholesterol ester transfer protein activity was practically unchanged (1.043 \pm 0.106 vs $1.070 \pm 0.106$, arbitrary units).

Lipoprotein kinetics. The significant reduction of LDL cholesterol and apo B during sitostanol treatment resulted from a diminished TR for LDL apo B (Table 3). The catabolism of LDL apo B, measured by FCR, was unchanged. The kinetic data of the light LDL fraction, calculated from the differences between the total and dense LDL apo B kinetics, were practically unchanged. Sitostanol ester significantly reduced the contents of cholesterol and apo B in the dense LDL fraction because of a diminished TR for LDL apo $\mathrm{B}(p=0.05)$.

Despite the significant elevation in HDL cholesterol and apo A I, FCR and TR for apo A I were unchanged by sitostanol ester (Table 4).

Intestinal transport and synthesis of cholesterol. Cholesterol absorption efficiency was markedly reduced during sitostanol ester treatment from $25 \pm 2$ to $9 \pm 2 \%$ (Table 5). Accordingly, the absolute amount of cholesterol absorbed was less than one-half the baseline value. Cholesterol synthesis and transport and its excretion as neutral sterols and intestinal cholesterol flux were all significantly increased. In addition, biliary secretion of cholesterol was increased. Bile acid synthesis was unaltered by sitostanol ester. 
Table 2. Serum and lipoprotein lipids before and during sitostanol ester treatment in eleven NIDDM men

\begin{tabular}{|c|c|c|c|}
\hline Variables & Control & Sitostanol ester & Change, $\%$ \\
\hline Total serum cholesterol $(\mathrm{mmol} / \mathrm{l})$ & $5.98 \pm 0.22$ & $5.62 \pm 0.21^{a}$ & $-5.8 \pm 2.3^{a}$ \\
\hline esterified $(\mathrm{mmol} / \mathrm{l})$ & $4.36 \pm 0.16$ & $4.08 \pm 0.15^{\mathrm{a}}$ & $-6.1 \pm 2.4^{a}$ \\
\hline free $(\mathrm{mmol} / \mathrm{l})$ & $1.62 \pm 0.07$ & $1.54 \pm 0.07$ & $-4.5 \pm 2.4$ \\
\hline Serum phospholipids (mmol/l) & $3.15 \pm 0.11$ & $3.04 \pm 0.10$ & $-3.2 \pm 2.1$ \\
\hline Total VLDL cholesterol (mmol/l) & $0.72 \pm 0.07$ & $0.63 \pm 0.08^{\mathrm{a}}$ & $-12.5 \pm 5.6^{\mathrm{a}}$ \\
\hline esterified & $0.38 \pm 0.04$ & $0.32 \pm 0.04^{\mathrm{a}}$ & $-13.1 \pm 7.9$ \\
\hline phospholipids (mmol/l) & $0.54 \pm 0.05$ & $0.48 \pm 0.06$ & $-9.4 \pm 8.8$ \\
\hline IDL cholesterol, total (mmol/l) & $0.30 \pm 0.03$ & $0.28 \pm 0.02$ & $-5.2 \pm 3.7$ \\
\hline esterified (mmol/l) & $0.20 \pm 0.02$ & $0.18 \pm 0.01^{\mathrm{a}}$ & $-10.7 \pm 3.6^{a}$ \\
\hline free $(\mathrm{mmol} / \mathrm{l})$ & $0.10 \pm 0.01$ & $0.10 \pm 0.01$ & $+5.8 \pm 4.9$ \\
\hline triglycerides $(\mathrm{mmol} / \mathrm{l})$ & $0.12 \pm 0.01$ & $0.13 \pm 0.01$ & $+17.2 \pm 5.9^{a}$ \\
\hline triglycerides (mmol/1) & $0.29 \pm 0.02$ & $0.30 \pm 0.02$ & $+1.1 \pm 3.9$ \\
\hline phospholipids (mmol/l) & $1.27 \pm 0.06$ & $1.16 \pm 0.05^{\mathrm{a}}$ & $-8.8 \pm 1.9^{a}$ \\
\hline LDL size $(\AA)$ & $243.9 \pm 2.2$ & $241.9 \pm 2.5$ & $-0.3 \pm 0.7$ \\
\hline HDL cholesterol, total (mmol/l) & $1.13 \pm 0.03$ & $1.24 \pm 0.05^{\mathrm{a}}$ & $+10.7 \pm 4.4^{\mathrm{a}}$ \\
\hline esterified $(\mathrm{mmol} / \mathrm{l})$ & $0.91 \pm 0.03$ & $1.00 \pm 0.05$ & $+9.6 \pm 4.4$ \\
\hline free $(\mathrm{mmol} / \mathrm{l})$ & $0.21 \pm 0.01$ & $0.24 \pm 0.01^{\mathrm{a}}$ & $+15.2 \pm 5.1^{\mathrm{a}}$ \\
\hline triglycerides (mmol/1) & $0.17 \pm 0.01$ & $0.18 \pm 0.01$ & $+12.3 \pm 5.8$ \\
\hline phospholipids (mmol/l) & $1.20 \pm 0.04$ & $1.28 \pm 0.05^{\mathrm{a}}$ & $+7.8 \pm 3.8$ \\
\hline apo A I (mg/100 ml) & $123.5 \pm 3.7$ & $128.8 \pm 3.7^{\mathrm{a}}$ & $+4.5 \pm 1.9^{a}$ \\
\hline apo $\mathrm{A}$ II $(\mathrm{mg} / 100 \mathrm{ml})$ & $28.8 \pm 0.7$ & $30.1 \pm 0.8$ & $+4.9 \pm 2.3$ \\
\hline
\end{tabular}

Data are given as mean $\pm \mathrm{SEM}$.

${ }^{a} p<0.05$ or less

Table 3. LDL kinetics before and during sitostanol ester treatment in eleven NIDDM men

\begin{tabular}{|c|c|c|c|c|c|c|}
\hline $\mathrm{LDL}$ & $\begin{array}{l}\text { Cholesterol } \\
(\mathrm{mmol} / \mathrm{l})\end{array}$ & $\begin{array}{l}\text { Apoprotein B } \\
(\mathrm{mg} / 100 \mathrm{ml})\end{array}$ & $\begin{array}{l}\text { Cholesterol/ } \\
\text { apoprotein B }\end{array}$ & $\begin{array}{l}\text { Sialic acids } \\
(\mu \mathrm{g} / 100 \mathrm{ml})\end{array}$ & $\begin{array}{l}\text { FCR } \\
\text { (pools/day) }\end{array}$ & $\begin{array}{l}\text { TR } \\
\left(\mathrm{mg} \cdot \mathrm{kg}^{-1} \cdot \mathrm{day}^{-1}\right)\end{array}$ \\
\hline \multicolumn{7}{|c|}{ LDL, total $(1.019-1.063 \mathrm{~g} / \mathrm{ml})$} \\
\hline Sitostanol ester & $3.3 \pm 0.2^{\mathrm{a}}$ & $60.5 \pm 2.8^{\mathrm{a}}$ & $2.06 \pm 0.02^{\mathrm{a}}$ & $28.5 \pm 2.6^{a}$ & $0.314 \pm 0.010$ & $8.5 \pm 0.4^{a}$ \\
\hline \multicolumn{7}{|c|}{ LDL, light (1.019-1.036 g/ml) } \\
\hline Control & $1.2 \pm 0.1$ & $20.2 \pm 2.6$ & $2.24 \pm 0.08$ & $12.7 \pm 1.4$ & $0.209 \pm 0.039$ & $2.0 \pm 0.5$ \\
\hline \multicolumn{7}{|c|}{ LDL, dense $(1.037-1.055 \mathrm{~g} / \mathrm{ml})$} \\
\hline Control & $2.5 \pm 0.1$ & $42.8 \pm 2.1$ & $2.26 \pm 0.04$ & $23.7 \pm 2.6$ & $0.420 \pm 0.032$ & $8.4 \pm 0.8$ \\
\hline Sitostanol ester & $2.1 \pm 0.1^{\mathrm{a}}$ & $36.3 \pm 2.2^{\mathrm{a}}$ & $2.30 \pm 0.08$ & $14.0 \pm 1.5^{\mathrm{a}}$ & $0.387 \pm 0.027$ & $6.5 \pm 0.8^{b}$ \\
\hline \multicolumn{7}{|c|}{ LDL, very dense $(1.056-1.063 \mathrm{~g} / \mathrm{ml})$} \\
\hline Control & $0.1 \pm 0.01$ & $2.1 \pm 0.3$ & $2.81 \pm 0.18$ & $4.7 \pm 0.7$ & - & - \\
\hline
\end{tabular}

Mean \pm SEM.

${ }^{\mathrm{a}} p<0.05$ or less; ${ }^{\mathrm{b}} p=0.05$

Table 4. HDL apo A I kinetics before and during sitostanol ester treatment in eleven NIDDM men

\begin{tabular}{|c|c|c|c|c|}
\hline Treatment & HDL cholesterol (mmol/l) & Apo A I (mg/dl) & FCR (pools/day) & $\mathrm{TR}\left(\mathrm{mg} \cdot \mathrm{kg}^{-1} \cdot \mathrm{day}^{-1}\right)$ \\
\hline Control & $1.13 \pm 0.03$ & $123.5 \pm 3.7$ & $0.230 \pm 0.013$ & $12.9 \pm 0.8$ \\
\hline Sitostanol ester & $1.24 \pm 0.05^{\mathrm{a}}$ & $128.8 \pm 3.7^{a}$ & $0.226 \pm 0.010$ & $13.0 \pm 0.7$ \\
\hline
\end{tabular}


H. Gylling et al.: Sitostanol ester in NIDDM

Table 5. Cholesterol absorption and metabolism before and during sitostanol ester treatment in eleven NIDDM men

\begin{tabular}{|c|c|c|}
\hline Variables & Control & $\begin{array}{l}\text { Sitostanol } \\
\text { ester }\end{array}$ \\
\hline Cholesterol absorption (\%) & $25.3 \pm 2.1$ & $8.6 \pm 1.8^{\mathrm{a}}$ \\
\hline $\begin{array}{l}\text { Dietary cholesterol absorbed } \\
\left(\mathrm{mg} \cdot \mathrm{kg}^{-1} \cdot \mathrm{day}^{-1}\right)\end{array}$ & $0.96 \pm 0.12$ & $0.42 \pm 0.12^{\mathrm{a}}$ \\
\hline $\begin{array}{l}\text { Total cholesterol absorbed } \\
\left(\mathrm{mg} \cdot \mathrm{kg}^{-1} \cdot \mathrm{day}^{-1}\right)\end{array}$ & $4.5 \pm 0.4$ & $1.8 \pm 0.4^{\mathrm{a}}$ \\
\hline \multicolumn{3}{|l|}{$\begin{array}{l}\text { Fecal steroids of cholesterol } \\
\text { origin }\left(\mathrm{mg} \cdot \mathrm{kg}^{-1} \cdot \mathrm{day}^{-1}\right)\end{array}$} \\
\hline $\begin{array}{l}\text { Bile acids } \\
\text { Neutral sterols } \\
\text { Total sterols }\end{array}$ & $\begin{array}{r}8.6 \pm 1.1 \\
13.5 \pm 1.1 \\
22.1 \pm 1.9\end{array}$ & $\begin{array}{c}8.4 \pm 1.2 \\
18.7 \pm 0.8^{\mathrm{a}} \\
27.1 \pm 1.7^{\mathrm{a}}\end{array}$ \\
\hline \multicolumn{3}{|l|}{$\begin{array}{l}\text { Fecal plant sterols } \\
\left(\mathrm{mg} \cdot \mathrm{kg}^{-1} \cdot \mathrm{day}^{-1}\right)\end{array}$} \\
\hline $\begin{array}{l}\text { Campesterol } \\
\text { Sitosterol } \\
\text { Sitostanol }\end{array}$ & $\begin{array}{l}1.4 \pm 0.1 \\
3.9 \pm 0.4 \\
0.4 \pm 0.1\end{array}$ & $\begin{array}{c}1.6 \pm 0.1 \\
5.0 \pm 0.3^{\mathrm{a}} \\
38.3 \pm 2.1^{\mathrm{a}}\end{array}$ \\
\hline Fecal fat $\left(\mathrm{mg} \cdot \mathrm{kg}^{-1} \cdot\right.$ day $\left.^{-1}\right)$ & $68.0 \pm 10.0$ & $70.0 \pm 8.0$ \\
\hline $\begin{array}{l}\text { Cholesterol synthesis } \\
\left(\mathrm{mg} \cdot \mathrm{kg}^{-1} \cdot \mathrm{day}^{-1}\right)\end{array}$ & $18.2 \pm 1.6$ & $22.7 \pm 1.3^{\mathrm{a}}$ \\
\hline $\begin{array}{l}\text { Intestinal cholesterol flux } \\
\left(\mathrm{mg} \cdot \mathrm{kg}^{-1} \cdot \mathrm{day}^{-1}\right)\end{array}$ & $18.0 \pm 1.1$ & $20.6 \pm 1.0^{\mathrm{a}}$ \\
\hline $\begin{array}{l}\text { Biliary cholesterol secretion } \\
\left(\mathrm{mg} \cdot \mathrm{kg}^{-1} \cdot \mathrm{day}^{-1}\right)\end{array}$ & $14.0 \pm 0.8$ & $16.2 \pm 0.6^{\mathrm{a}}$ \\
\hline $\begin{array}{l}\text { Cholesterol transport } \\
\left(\mathrm{mg} \cdot \mathrm{kg}^{-1} \cdot \mathrm{day}^{-1}\right)\end{array}$ & $19.1 \pm 1.6$ & $23.1 \pm 1.4^{\mathrm{a}}$ \\
\hline
\end{tabular}

Data are given as mean \pm SEM. $^{a} p<0.05$ or less

Table 6. Serum squalene and non-cholesterol sterol proportions $\mathrm{s}^{\mathrm{a}}$ before and during sitostanol ester treatment in eleven NIDDM men

\begin{tabular}{|c|c|c|}
\hline Variables & Control & Sitostanol ester \\
\hline Cholesterol, $\mathrm{mg} / 100 \mathrm{ml}$ & $222.1 \pm 8.1$ & $206.6 \pm 8.0^{b}$ \\
\hline Squalene $^{\mathrm{a}}$ & $31.4 \pm 3.7$ & $32.5 \pm 2.9$ \\
\hline$\Delta 8$-cholestenol ${ }^{\mathrm{a}}$ & $32.4 \pm 2.3$ & $35.8 \pm 3.0^{b}$ \\
\hline Desmosterol $^{\mathrm{a}}$ & $109.3 \pm 6.0$ & $121.3 \pm 5.7^{b}$ \\
\hline Lathosterol $^{\mathrm{a}}$ & $185.3 \pm 12.5$ & $212.3 \pm 19.1^{b}$ \\
\hline Campesterol $^{\mathrm{a}}$ & $240.7 \pm 27.3$ & $134.9 \pm 15.0^{\mathrm{b}}$ \\
\hline Sitosterol $^{\mathrm{a}}$ & $110.3 \pm 12.2$ & $62.9 \pm 6.5^{b}$ \\
\hline Cholestanol $^{a}$ & $94.4 \pm 6.6$ & $84.0 \pm 6.0^{\mathrm{b}}$ \\
\hline
\end{tabular}

Data are given as mean \pm SEM.

a $10^{2} \times \mathrm{mmol} / \mathrm{mol}$ of cholesterol; ${ }^{b} p<0.05$ or less

The unchanged fecal campesterol output suggested that the amount of dietary plant sterols were unchanged during the intervention, while the small increment in fecal sitosterol was due to its presence in the sitostanol preparation.

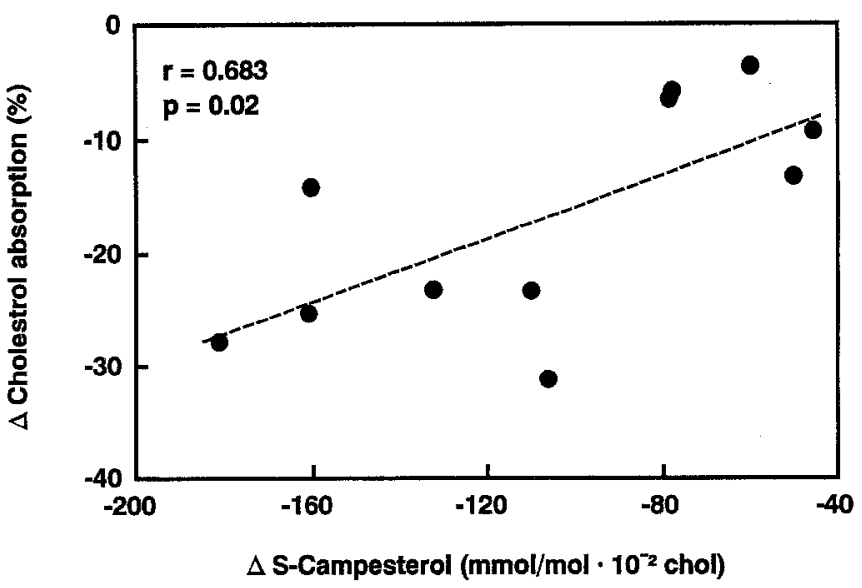

Fig. 1. The relationship between sitostanol ester margarine-induced changes in cholesterol absorption efficiency and serum campesterol proportion in eleven men. $y=-1.83+0.14 x$

Non-cholesterol sterols. During sitostanol ester treatment, serum cholesterol precursor proportions, except squalene, were significantly elevated and serum plant sterol proportions were reduced to one-half (Table 6). In addition, serum cholestanol proportion was significantly lowered.

Correlations. During the control period, LDL cholesterol concentration was significantly negatively correlated with FCR for LDL apo B, and cholesterol and bile acid synthesis $(r=-0.732,-0.633$ and $-0.681, p<0.05)$. Cholesterol synthesis was related to the proportion of serum squalene $(r=0.715, p<0.05)$, LDL cholesterol level $(r=-0.633, p=0.05)$ and cholesterol absorption efficiency $(r=-0.601)$. In addition, the serum lathosterol proportion was significantly related to FCR for LDL apo B $(r=0.667, p<0.05)$. Cholesterol absorption efficiency was significantly related to the proportions of serum campesterol and sitosterol $(r=0.717$ and $0.661, p<0.05$ ).

During sitostanol ester treatment, LDL cholesterol was significantly related to TR for LDL apo B but not to other metabolic parameters. The reduction in cholesterol absorption efficiency was correlated with that of the proportion of serum campesterol $(r=+0.683$, $p<0.05$, Fig. 1) and HDL cholesterol level $(r=$ $+0.638, p=0.05$ ).

\section{Discussion}

The present results showed that sitostanol ester-containing rapeseed oil margarine was an effective and well-tolerated hypocholesterolaemic nutrient in hypercholesterolaemic NIDDM. Cholesterol absorption was reduced to one-third, cholesterol synthesis was enhanced and TR for LDL apo B was reduced so that the serum levels of total, VLDL and LDL cholesterol and LDL apo B were reduced, and those of HDL cholester- 
ol and apo A I were increased by sitostanol ester. The reduced serum levels during sitostanol ester treatment occurred mainly in the dense $(1.037-1.055 \mathrm{~g} / \mathrm{ml})$, virtually not at all in light $(1.019-1.036 \mathrm{~g} / \mathrm{ml})$ LDL fraction, and was caused by reduced TR for LDL apo B.

The control cholesterol absorption efficiency was lower and cholesterol synthesis, measured by the balance technique or the cholesterol precursor proportions, was markedly higher in the NIDDM men than in a group of 50-year-old men $[19,36]$. Cholesterol absorption in NIDDM has been shown to be low in a hypertriglyceridaemic group but not in other diabetic subgroups [37]. The low cholesterol absorption efficiency in the present series could result from diabetes itself or be contributed to by rapeseed oil fat or a relatively large plant sterol intake. Thus, the serum plant sterol proportions, instead of being low as suggested by low cholesterol absorption efficiency, were above the level of the 50-year-old men [36]. Dietary plant sterols can be absorbed [16] and inhibit cholesterol absorption. However, low plant sterol proportions in NIDDM subjects were suggested to reflect a lowered cholesterol absorption efficiency, although unchanged lathosterol proportion did not indicate compensatorily increased cholesterol synthesis [38]. In fact, the latter and high bile acid synthesis have been observed in some NIDDM subgroups $[37,39,40]$, these findings being in agreement with the present results. In vitro studies have shown that an altered LDL composition and hyperglycaemia in the presence of hyperinsulinaemia $[41,42]$ stimulate cholesterol synthesis in mononuclear cells. According to the present sterol balance and noncholesterol sterol values low cholesterol absorption efficiency activates cholesterol synthesis and turnover even during good glycaemic control in hypercholesterolaemic patients with NIDDM.

In the present series the decrease in serum total and LDL cholesterol by up to $16 \%$ is less than the respective $15-33 \%$ reduction in children with familial hypercholesterolaemia consuming a daily sitostanol dose of $1.5 \mathrm{~g}$ [14]. In contrast to non-diabetic subjects $[14,15$, 17], in the present diabetic population also VLDL and IDL cholesterol were significantly decreased and HDL cholesterol and apo A I increased by sitostanol. These changes decreased core cholesterol from VLDL and IDL and increased surface lipids in HDL. The percent of esterified cholesterol and cholesterol ester transfer protein activity, in general low in NIDDM [43], were unaffected by sitostanol treatment. Despite the slight but significant increase in the apo A I concentration its kinetic parameters were inconsistently changed during the sitostanol ester treatment. The accumulation of free cholesterol in HDL suggests that the reverse cholesterol transport may be accentuated during sitostanol ester treatment.

Enhanced cholesterol synthesis increases biliary cholesterol and plant sterol secretion [44]. Thus, the decrease in serum plant sterols was apparently caused by both improved biliary output and reduced absorption. The decrease of the serum plant sterol proportions was related to that of cholesterol absorption efficiency, indicating that the quantitation of serum plant sterols offers a potential, less laborious means with which to study changes in cholesterol absorption without isotopes and fecal collections.

Hypolipidaemic therapy with cholesterol malabsorption by ketoconazole [22], neomycin [45] or sitostanol ester in the present study decreases TR, less so fractional catabolism for LDL apo B. The main reduction of LDL cholesterol, apo B and TR occurred in the dense LDL fraction with no compositional change, while the very dense fraction became apo B enriched. These results are in concert with simvastatin-induced changes in primary hypercholesterolaemia [46]. It could be hypothesized that sitostanol ester decreased cholesterol absorption efficiency so that less intestinal chylomicron cholesterol entered the liver, resulting in upregulation of hepatic cholesterol synthesis and probably LDL receptor activity. The possibly upregulated LDL receptor activity could not be seen by increased FCR for any LDL subfraction, but the decreased VLDL and IDL cholesterol levels suggest that removal of these cholesterol-rich particles was increased by upregulated receptor activity lowering LDL removal and decreasing their conversion to LDL. The decrease of LDL apo B transport could, according to a previous report [47], indicate enhanced receptor activity. The finding agrees with an earlier study in which simvastatin increased the direct catabolism of VLDL particles and FCR of IDL, not of LDL, so that the synthesis of LDL was reduced [46].

Desialylated LDL has been considered to be atherogenic [48]. Thus, in patients with coronary artery disease $[49,50]$ and in both types of diabetes [51] the sialic acid content is decreased in LDL. Although desialylated and glycated LDL are effectively taken up by human aortic intimal cells [51], in the NIDDM subjects studied here the LDL sialic acid/protein ratio was not correlated with removal of total or dense apo B (data not shown).

The present kinetic results for total LDL apo B were similar to those found in non-diabetic subjects [22]. The previous kinetic studies for total LDL have shown varying FCR and TR values in NIDDM [52-54], while those for dense LDL particles have not been studied previously in NIDDM. In most but not all non-diabetic hyperlipidaemic subjects the dense LDL fraction was cleared slower than the light fraction [55-57], while in almost all of our diabetic patients the dense LDL fraction was cleared faster than the light fraction. In contrast to earlier findings in familial hypercholesterolaemia [55], none of the radioactivity in the dense fraction was transferred to the light fraction in our diabetic subjects. Thus, the kinetics of total LDL is normal in hypercholesterolaemic NIDDM under good glycaemic control. 
In conclusion sitostanol ester margarine treatment reduced serum total, VLDL, and LDL cholesterol levels by inhibiting cholesterol absorption, increasing cholesterol synthesis and reducing TR of the dense LDL fraction. A simple and well-tolerated dietary use of the sitostanol ester margarine preparation in doses of $30 \mathrm{~g}$ with $3 \mathrm{~g}$ of sitostanol per day offers a significant cholesterol-lowering measure in NIDDM subjects with mild to moderate hypercholesterolaemia.

Acknowledgements. The Finnish Heart Research Foundation, Finnish Academy for Medical Sciences, Juho Vainio Foundation and University of Helsinki have supported the study with grants. The expert technical and secretarial assistance of Ms. R. Selivuo, O. Ahlroos, E. Gustafsson, P. Hoffström, L. Kaipiainen, E. Kempas, R. Nissilä, L.Saikko, A. Salolainen and S. Aarnio is greatfully acknowledged.

\section{References}

1. Garcia MJ, McNamara PM, Gordon T, Kannel WB (1974) Morbidity and mortality in diabetics in the Framingham population: sixteen year follow-up study. Diabetes 23: 105111

2. Kannel WB, McGee DL (1979) Diabetes and cardiovascular risk factors: the Framingham study. Circulation 59: 8-13

3. Stamler J, Wentworth D, Neaton J, Schoenberger JA, Feigal D, for the MRFIT Research Group (1984) Diabetes and risk of coronary, cardiovascular, and all causes mortality: findings for 356,000 men screened by the multiple risk factor invervention trial (MRFIT). Circulation 70 [Supp1 2]: II-161

4. Hanefeld M, Schmechel H, Julius U et al. (1991) Five-year incidence of coronary heart disease related to major risk factors and metabolic control in newly diagnosed non-insulin dependent diabetes. The diabetes intervention study (DIS). Nutr Metab Cardiovasc Dis 1: 135-140

5. Peterson DW, Nichols CW, Peek NF, Chaikoff IL (1956) Depression of cholesterol in human subjects consuming butter containing soy sterols. Fed Proc 15: 569-572

6. Grundy SM, Ahrens EH Jr, Davignon J (1969) The interaction of cholesterol absorption and cholesterol synthesis in man. J Lipid Res 10: 304-315

7. Kudchodkar BJ, Horlick L, Sodhi HS (1976) Effects of plant sterols on cholesterol metabolism in man. Atherosclerosis 28: $239-248$

8. Mattson FH, Volpenheim FA, Erickson BA (1977) Effect of plant sterol esters on the absorption of dietary cholesterol. $\mathrm{J}$ Nutr 107: 1139-1146

9. Grundy SM, Mok HYI (1977) Determination of cholesterol absorption in man by intestinal perfusion. J Lipid Res 18: 263-271

10. Mattson FH, Grundy SM, Crouse JR (1982) Optimizing the effect of plant sterols on cholesterol absorption in man. Am J Clin Nutr 35: 697-700

11. Lees AM, Mok HYI, Lees RS, McCluskey MA, Grundy SM (1977) Plant sterols as cholesterol-lowering agents: clinical trials in patients with hypercholesterolemia and studies of sterol balance. Atherosclerosis 28: 325-338

12. Sugano M, Morioka H, Ikeda I (1977) A comparison of hypocholesterolemic activity of $\beta$-sitosterol and $\beta$-sitostanol in rats. J Nutr 107: 2011-2019

13. Hassan AS, Rampone AJ (1979) Intestinal absorption and lymphatic transport of cholesterol and $\beta$-sitostanol in the rat. J Lipid Res 20: 646-653
14. Becker M, Staab D, von Bergmann K (1993) Treatment of severe familial hypercholesterolemia in childhood with sitosterol and sitostanol. J Pediatr 122: 292-296

15. Heinemann T, Leiss O, von Bergmann K (1986) Effect of low-dose sitostanol on serum cholesterol in patients with hypercholesterolemia. Atherosclerosis 61: 219-223

16. Vanhanen HT, Miettinen TA (1992) Effects of unsaturated and saturated dietary plant sterols on their serum contents. Clin Chim Acta 205: 97-107

17. Vanhanen HT, Blomqvist S, Ehnholm C et al. (1993) Serum cholesterol, cholesterol precursors, and plant sterols in hypercholesterolemic subjects with different apoE phenotypes during dietary sitostanol ester treatment. J Lipid Res 34: $1535-1544$

18. Kesäniemi YA, Ehnholm C, Miettinen TA (1987) Intestinal cholesterol absorption efficiency in man is related to apoprotein E phenotype. J Clin Invest 80: 578-581

19. Miettinen TA, Kesäniemi YA (1989) Cholesterol absorption: regulation of cholesterol synthesis and elimination and within-population variations of serum cholesterol levels. Am J Clin Nutr 49: 629-635

20. Knuts L-R, Rastas M, Haapala P (1991) Micro-Nutrica: Version 1.0. Kansaneläkelaitos, Helsinki

21. Lipid and lipoprotein analysis (1974) Manual of laboratory operations, lipid research clinic program. Washington D.C., DHEW Publication No NIH/75-628

22. Gylling H, Vanhanen H, Miettinen TA (1993) Effects of ketoconazole on cholesterol precursors and low density lipoprotein kinetics in hypercholesterolemia. J Lipid Res 34: 59-67

23. Miettinen TA (1982) Gas-liquid chromatographic determination of fecal neutral sterols using a capillary column. Clin Chim Acta 124: 245-248

24. Groener JEM, Pelton RW, Kostner GM (1986) Improved estimation of cholesteryl ester transfer exchange activity in serum or plasma. Clin Chem 32: 283-286

25. Catignani GL, Bieri JG (1983) Simultaneous determination of retinol and $\alpha$-tocopherol in serum or plasma by liquid chromatography. Clin Chem 29: 708-712

26. Svennerholm L (1957) Quantitative estimation of sialic acids. II. A colorimetric resorcinol-hydrochloric acid method. Biochim Biophys Acta 24: 604-611

27. Miettinen T, Takki-Luukkainen I-T (1959) Use of butyl acetate in determination of sialic acid. Acta Chem Scand 13: 856-858

28. Crouse JR, Grundy SM (1978) Evaluation of a continuous isotope feeding method for measurement of cholesterol absorption in man. J Lipid Res 19: 967-971

29. Bolin DW, King RP, Klosterman EW (1952) A simplified method for the determination of chromic oxide $\left(\mathrm{Cr}_{2} \mathrm{O}_{3}\right)$ when used as an index substance. Science 116: 634-635

30. Miettinen TA, Ahrens EH Jr, Grundy SM (1965) Quantitative isolation and gas-liquid chromatographic analysis of total dietary and fecal neutral steroids. J Lipid Res 6:411-424

31. Grundy SM, Ahrens EH Jr, Miettinen TA (1965) Quantitative isolation and gas-liquid chromatographic analysis of total fecal bile acids. J Lipid Res 6: 397-410

32. Vega GL, Gylling H, Nichols AV, Grundy SM (1991) Evaluation of a method for study of kinetics of autologous apolipoprotein A-I. J Lipid Res 32: 867-875

33. McFarlane AS (1958) Efficient trace-labelling of proteins with iodine. Nature 182: 53

34. Bilheimer DW, Eisenberg S, Levy RI (1972) The metabolism of very low density lipoproteins proteins. I.Preliminary in vitro and in vivo observations. Biochim Biophys Acta 260: 212-221

35. Matthews CME (1957) The theory of tracer experiments with ${ }^{131}$ I-labelled plasma proteins. Phys Med Biol 2: 36-53 
36. Miettinen TA, Tilvis RS, Kesäniemi YA (1989) Serum cholestanol and plant sterol levels in relation to cholesterol metabolism in middle-aged men. Metabolism 38: 136-140

37. Briones ER, Steiger DL, Palumbo PJ (1986) Sterol excretion and cholesterol absorption in diabetics and nondiabetics with and without hyperlipidemia. Am J Clin Nutr 44: 353-361

38. Sutherland WH, Scott RS, Lintott CJ, Robertson MC, Stapely SA, Cox C (1992) Plasma non-cholesterol sterols in patients with non-insulin dependent diabetes mellitus. Horm Metab Res 24: 172-175

39. Abrams JJ, Ginsberg H, Grundy SM (1982) Metabolism of cholesterol and plasma triglycerides in nonketotic diabetes mellitus. Diabetes 31: 903-910

40. Andersen E, Hellström P, Hellström K (1986) Cholesterol and bile acid metabolism in middle-aged diabetics. Diabete Metab 12: 261-267

41. Tomkin GH, Owens D (1991) Abnormalities of cholesterol metabolism in diabetes. Proc Nutr Soc 50: 583-589

42. Owens D, Maher V, Collins P, Johnson A, Tomkin G (1990) Cellular cholesterol regulation - a defect in type 2 (non-insulin-dependent) diabetic patients in poor metabolic control. Diabetologia 33: 93-99

43. Fielding CJ, Reaven GM, Liu G, Fielding PE (1984) Increased free cholesterol in plasma low and very low density lipoproteins in non-insulin-dependent diabetes mellitus: its role in the inhibition of cholesteryl ester transfer. Proc Natl Acad Sci USA 81:2512-2516

44. Miettinen TA, Tilvis RS, Kesäniemi YA (1990) Serum plant sterols and cholesterol precursors reflect cholesterol absorption and synthesis in volunteers of a randomly selected male population. Am J Epidemiol 131: 20-31

45. Kesäniemi YA, Grundy SM (1984) Turnover of low density lipoproteins during inhibition of cholesterol absorption by neomycin. Arteriosclerosis 4: 41-48

46. Gaw A, Packard CJ, Murray EF et al. (1993) Effects of simvastatin on apoB metabolism and LDL subfraction distribution. Arterioscler Thromb 13: 170-189

47. Grundy SM, Vega GL, Bilheimer DW (1985) Kinetic mechanisms determining variability in low density lipoprotein levels and rise with age. Arteriosclerosis 5: 623-630
48. Tertov VV, Sobenin IA, Gabbasov ZA, Popov EG, Orekhov AN (1989) Lipoprotein aggregation as an essential condition of intracellular lipid accumulation caused by modified low density lipoproteins. Biochem Biophys Res Comm 163: 489494

49. Orekhov AN, Tertov VV, Mukhin DN (1991) Desialylated low density lipoprotein-naturally occurring modified lipoprotein with atherogenic potency. Atherosclerosis 86: 153161

50. Jaakkola O, Solakivi T, Tertov VV, Orekhov AN, Miettinen TA, Nikkari T (1993) Characteristics of low-density lipoprotein subfractions from patients with coronary artery disease. Coron Artery Dis 4: 379-385

51. Sobenin IA, Tertov VV, Koschinsky T et al. (1993) Modified low density lipoprotein from diabetic patients causes cholesterol accumulation in human intimal aortic cells. Atherosclerosis 100: 41-54

52. Howard BV, Abbott WGH, Beltz WF et al. (1987) Integrated study of low density lipoprotein metabolism and very low density lipoprotein metabolism in non-insulin-dependent diabetes. Metabolism 36: 870-877

53. Taskinen M-R, Packard CJ, Shepherd J (1990) Effect of insulin therapy on metabolic fate of apolipoprotein B-containing lipoproteins in NIDDM. Diabetes 39: 1017-1027

54. Kissebah AH (1987) Low density lipoprotein metabolism in non-insulin-dependent diabetes mellitus. Diab Metab Rev 3: $619-651$

55. Teng B, Sniderman AD, Soutar AK, Thompson GR (1986) Metabolic basis of hyperapobetalipoproteinemia. J Clin Invest $77: 663-672$

56. Vega GL, Grundy SM (1986) Kinetic heterogeneity of low density lipoproteins in primary hypertriglyceridemia. Arteriosclerosis 6: $395-406$

57. Vega GL, Grundy SM (1992) Occurrence of species of lowdensity lipoprotein with defective clearance in patients with primary moderate hypercholesterolaemia. J Intern Med 232: $405-413$ 